\title{
The Illegal Dumping of Waste in Forest Areas - Evidence from Rural Territory
}

\author{
Andreea Lămăşanu, Florin - Constantin Mihai \\ Alexandru Ioan Cuza University of Iasi, Romania \\ Corresponding author e-mail address: andreea_lamasanu@yahoo.com (A. Lămăşanu)
}

\begin{abstract}
Household waste generated is often uncolleted in rural areas causing various types of pollution like: air and water pollution, soil pollution and the aesthetic degradation of the landscape. The environmental legislation proposed by the European Union was transposed on the national legislation but the implementation process was difficult because of particular situations encountered in practice. Rudimentary infrastructure of waste management and limited access to waste collection services lead to uncontrolled household waste disposal. In this context, the geographical location of rural settlements influences the way of waste disposal either on river banks or open dumps placed on roadsides or forest areas with various environmental implications. Those, forest areas in the proximity of human settlements or recreation areas become vulnerable to waste pollution. Even if local authorities are obliged to provide waste collection facilities since July 16, 2009 the illegal dumping of waste in forests is still present. This situation is reflected by field observations from Suceava and Neamt counties. Usually forest areas affected by uncontrolled waste disposal are located in hilly regions or subcarpathian areas. The degradation of these areas is visible and this can have a negative influence not only on the environment but also on tourism activities.
\end{abstract}

Keywords: waste management, forest areas, uncontrolled waste disposal

\section{Introduction}

Increasing the amount of waste is no longer a novelty, but waste management should be a priority for any local authority. We are aware that we live in a society where the consumption of products is enormous, and it inevitably leads to an increasing number of "useless materials" which can be recovered by developing waste management sector.

Factors that may influence the amount of waste generated are multiple, for example, income of the population in developed countries could enable a higher consumption of products reflecting the high share of recyclables in household waste composition. Also, the large number of population in some low-income countries, would lead inevitably to an increasing amounts of biodegradable waste generated.

Leaving aside the social inequities a particularly importance in waste generation and their treatment play the consumer behavior and the emergence of new packaged products on the market. Thus, educating citizens in 
environmental spirit is essential and must take into account the practice of waste prevention and recycling.

Waste management issues can be seen in the improper waste disposal facilities. Dumping waste outside special sites generate serious environmental problems.

A simple landfill site that does not meet environmental standards may adversely affect soil quality, can contaminate groundwater, can pollute air and damage the local landscape.

This research aims to exhibit the situation of local waste management and its environmental influences in Romanian rural areas.

\section{Materials and methods}

The study area is geographically located in north-eastern Romania and administratively situated of the NorthEast Development Region.

First, this paper analysis the dysfunctions of current waste management systems from rural areas, which encouraging the illegal dumping on forest areas related to the field observations from 2009-2011.

A comparative analysis is done regarding the access of rural population to sanitation services using local waste statistics provided by Environmental Protection Agencies, for the period 2003-2008 (latest available data).

Secondly, this paper examines the implementation as a new EU member of EU waste management regulations on rural areas and its implications at the local level.

\section{Results}

Processing the statistical data we met two different situations.

On the one hand, rural population access to sanitation services from Neamt, County has remained constant over the past 10 years, so that in 2008 only $10 \%$ of the population benefits of waste collection services (Fig. 1).

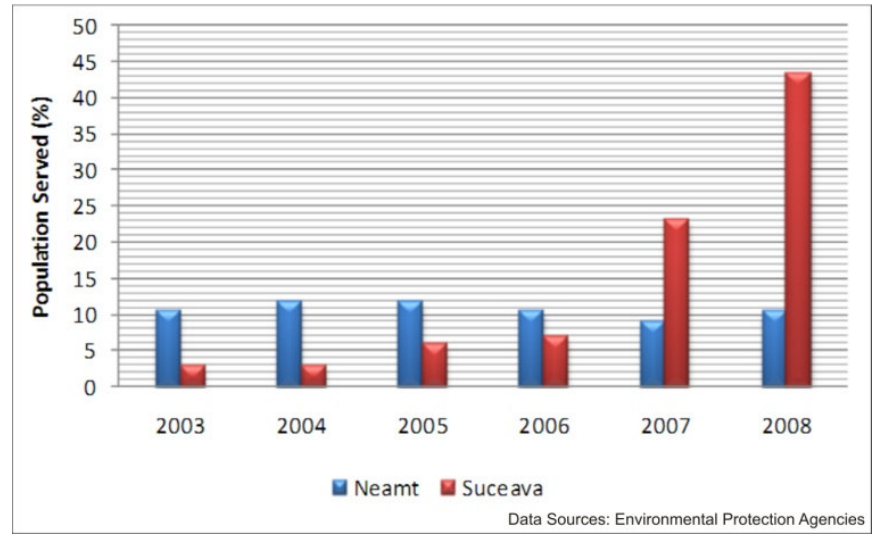

Figure 1 Rural population served by sanitation services 
On the other hand, in Suceava County statistics show that over $40 \%$ of the rural population have access to sanitation services in 2008, compared to only 3\% in 2003 (Fig. 1).

Fields observations from 2009 confirm that in rural areas of Neamt County sanitation services are lacking or inadequately performed. Thus, we noticed that the forests around rural areas have become real dumps. It seems that the most affected are hills and plateau regions, where geographical conditions favor the bad practices of the inhabitants.

Forest areas around rural communities: Brusturi, Oglinzi, Făurei or tourist resting places are affected by these inappropriate dumpsites (Fig. 2).
Open dumps are not missing in Suceava County, because the authorities do not take necessary measures to stop the illegal dumping of waste.

In the Carpathian areas, near settlements Râşca, Boroaia, Mălini, one can see forest areas affected by visible aesthetic degradation. Because of proximity to rural settlements, the rivers and tributary streams from mountain region are more vulnerable to waste pollution. Most of the waste generated and uncollected is partially recovered in households, and remaining waste is disposed in open dumps (Apostol and Mihai, 2011).

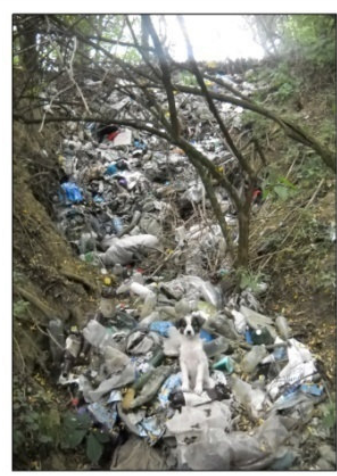

Oglinzi Village - 2009

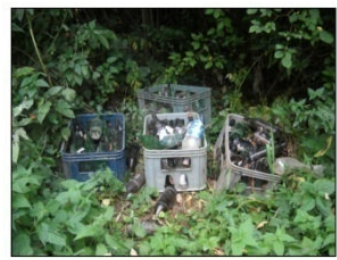

Brusturi Village - 2009

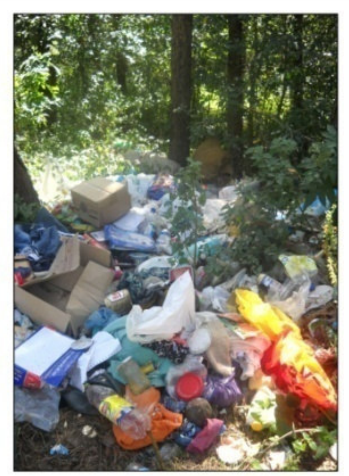

Poiana Largului Village - 2009

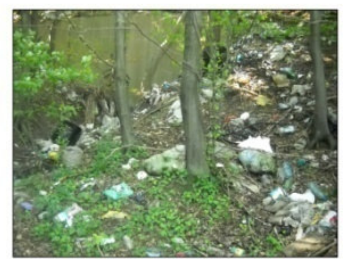

Făurei Village - 2011

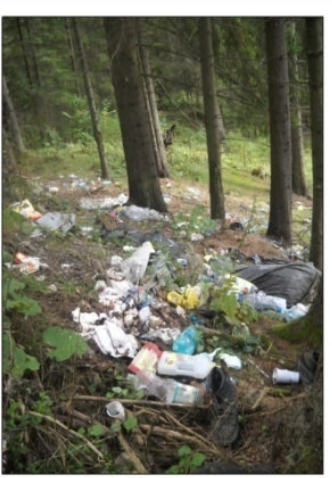

Pipirig Pass - 2009

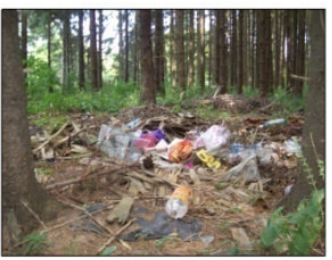

Râşca Village - 2011

Figure 2 Waste dumping in forest areas - field observations 


\section{Discussion}

New EU members are facing with illegal dumping of waste on rural territory and they have difficulties to accomplish the EU waste management regulations (Apostol and Mihai, 2011; Orosz and Fakezaz, 2008; Kulczycka and Zygmunt, 2008).

European Union forced the construction of sanitary landfills, according to environmental standards and at the same time the closure of old dumps from urban and rural territory in order to minimize the environmental pollution and to rehabilitate the degraded sites.

The implementation of European standards has occurred according to local particularities of each Member State (Mazzanti and Zoboli, 2011; Pires et al., 2011).

In Romania, building new landfills was not completed until the date set for the closure of non-compliant dumpsites. This fact has generated an unpleasant situation in which the costs of sanitation services have increased because the waste had to be transported to the nearest newly built landfill.

The most affected are rural areas where some local authorities have abandoned sanitation services for financial reasons. Moreover, due to lack of environmental education of local population, in many areas appeared household waste dumped on river banks, on roadsides or forest areas. The dumping of waste in inappropriate places have created a desolate landscape and affected tourist areas.

As we have seen in the analysis of statistical data and field observations, the reality existing in Romanian rural areas is one that exceeds the measures taken by local authorities. Although waste management infrastructure is still rudimentary in many rural communities, by 2009 it was able to cover the needs of residents.

Current high price of transport and waste disposal causes problems which are beyond the control of local authorities. Acquis implementation is difficult to achieve in rural areas because of the absence of a coherent waste management policy related to natural and socio-economic conditions. Fines for illegal dumping of waste in inappropriate places are required by low but the rural authorities sometimes avoid to apply them because it is difficult for they to identify the people who are responsible for these bad practices.

Ichinose and Yamamoto (2011) show that the number of illegal dumping incidents decreases as the number of intermediate waste management facilities increases.

Development of environmental polices requires the involvement of public authorities and in the same time the support of civil society. People must be aware to their environmental issues and to contribute for a local 
sustainable development. Management plans of waste and recycling should be developed in order to sustain environmental, economic, and social development principles (Demirbas, 2011).

\section{Conclusion}

The implementation of EU regulations on waste management in Romanian rural space is still difficult and the improper sanitation services lead to various environmental issues.

Low economic support, incompetence and lack of interest shown by local authorities and sometimes the lack of ecological education among citizens contribute to aesthetic degradation of forest areas in proximity of human settlements.

Development of proper waste management facilities and extension of sanitation services in rural areas should be the priority for environmental investments.

\section{Acknowledgments}

This work was supported by the European Social Fund in Romania, under the responsibility of the Managing Authority for the Sectoral Operational Programme for Human Resources Development 2007-2013 [grant POSDRU/CPP 107/DMI $1.5 / \mathrm{S} / 78342]$.

\section{References}

Apostol, L., Mihai, F., 2011. The process of closing down rural landfills.

Case study: Neamț County.Present Evironment and Sustainable Development 5 (2), 167- 174

Demirbas, A., 2011. Waste management, waste resource facilities and waste conversion processes. Energy Conversion and Management 52, 1280-1287

Ichinose, D., Yamamoto, M., 2011.On the relationship between the provision of waste management service and illegal dumping. Resource and Energy Economics 33, 79-93

Kulczycka, J., Zygmunt, K., 2008.

Principles of municipal waste management in Poland and selected regions of Europe. Polish Journal of Chemical Technology 10 (4), 28-33

Mazzanti, M., Zoboli R., 2008.Waste generation, waste disposal and policy effectiveness. Evidence on decoupling from the European Union. Resources, Conservation and Recycling, 52, 12211234

Orosz, Z., Fazekas, I., 2008. Challenges of municipal waste management in Hungary. AGD Landscape \& Environment 2 (1), 78 85

Pires, A., Martinho, G., Chang,N.B., 2011. Solid waste management in European countries: A review of systems analysis techniques. Journal of Environmental Management, 92, 1033-1050.

\section{How to cite this paper:}

Lămăşanu, A., Mihai, F.-C., 2012: The Illegal Dumping of Waste in Forest Areas - Evidence from Rural Territory. In: Horodnic, S.-A., Duduman, M.-L. Palaghianu, C. (eds.): Proceedings of the International Conference Integrated Management of Environmental Resources - Suceava, November 4-6th, 2011. Editura Universității „Ş̧tefan cel Mare” Suceava, Romania, 46 50. 